\title{
Apoptosis induced by yessotoxins in Hela human cervical cancer cells in vitro
}

\author{
MIN PANG ${ }^{1 *}$, CHUN-LEI GAO ${ }^{2 *}$, ZHEN-XING WU ${ }^{3}$, NING LV $^{3}$, \\ ZONG-LING WANG ${ }^{2}$, XUE-XI TANG ${ }^{1}$ and PEI QU ${ }^{2}$ \\ ${ }^{1}$ College of Marine Life Sciences, Ocean University of China, Qingdao 266003; \\ ${ }^{2}$ The First Institute of Oceanography, State Oceanic Administration, Qingdao 266061; ${ }^{3}$ Technical Center, \\ Shandong Entry-Exit Inspection and Quarantine Bureau, Qingdao 266002, P.R. China
}

Received December 21, 2009; Accepted April 15, 2010

DOI: $10.3892 / \mathrm{mmr} 00000307$

\begin{abstract}
To investigate the apoptotic effects of an extract of red-tide algae, Protoceratium reticulatum, on $\mathrm{HeLa}$ cells, we used liquid chromatography-tandem mass spectrometry, optical microscopy, Hoechst 33342/propidine iodide staining, and DNA gel electrophoresis to analyze its constituents and toxicity, as well as rhodamine 123 staining to investigate changes in mitochondrial membrane potential. Analysis showed that the $P$. reticulatum extract contained the yessotoxins (YTXs) homo-YTX, 45-OH-YTX and 45-OHhomo-YTX. The results indicated that $P$. reticulatum extract negatively influences HeLa cells and induces their apoptosis.
\end{abstract}

\section{Introduction}

Yessotoxins (YTXs) are sulfated polyether compounds (1) produced by the dinoflagellates Protoceratium reticulatum, Gonyaulax spinifera and Lingulodinium polyedrum $(2,3)$. Analogue compounds of YTXs are a concern in seafood quality monitoring and the shellfish industries. YTXs were

Correspondence to: Dr Min Pang, College of Marine Life Sciences, Ocean University of China, Qingdao 266003, P.R. China

E-mail:pm_cat@hotmail.com

${ }^{*}$ Contributed equally

Abbreviations: DMSO, dimethyl sulphoxide; DSP, diarrheic shellfish poisoning; DTX, dinophysis toxins; FCS, fetal calf serum; G. spinifera, Gonyaulax spinifera; HPLC, high-performance liquid chromatography; L. polyedrum, Lingulodinium polyedrum; LC-MS/ MS, liquid chromatography-tandem mass spectrometry; MTP, mitochondrial transmembrane potential; MTT, 3-(4,5-dimethylthiazol-2-yl)-2,5-diphenyltetrazolium bromide; NRC, National Research Council; OA, okadaic acid; P. reticulatum, Protoceratium reticulatum; PBS, phosphate-buffered saline; PI, propidium iodide; PRE, P. reticulatum extract; Rh123, rhodamine 123; RNase A, ribonuclease A; YTX, yessotoxin

Key words: yessotoxins, apoptosis, Hela cells first isolated and identified from the scallop Patinopecten yessoensis at Mutsu Bay in Japan in 1987 (1). Over the past two years, YTXs have been detected in shellfish around the world, including the coastal cities of China (4-9).

YTXs were initially classified as a diarrheic shellfish poisoning (DSP) toxin since they were usually extracted with DSP toxins such as okadaic acid (OA) and dinophysis toxins (DTXs). However, subsequent research found that, unlike OA and DTXs, YTXs do not induce diarrhea $(1,10)$, nor do they inhibit protein phosphatase 2A activity (10). The structure of YTXs was shown to be similar to that of brevetoxins and ciguatoxins (11). In 2002, the European Union Commission formally delisted YTXs as a DSP toxin (12). However, YTXs may accumulate in shellfish and are a health concern for human consumption (13).

YTXs are mainly produced by the dinoflagellates $P$. reticulatum, $G$. spinifera and $L$. polyedrum $(2,3)$. $P$. reticulatum is found worldwide and was the first biological source reported to produce YTXs (2). L. polyedrum and $G$. spinifera have been identified in several European countries and in the US (7,14-16). In China, $P$. reticulatum, G. spinifera and $L$. polyedrum have been found in the silt of the Yellow Sea, and G. spinifera has been found in the offshore areas of Shandong and Zhejiang provinces.

The toxic effects of YTXs have been studied in different contexts. YTXs administered through ingestion or intraperitoneal injection induce cardiotoxic effects in mice (10,17-19). At the molecular level, YTXs have been found to induce apoptosis in vitro $(20,21)$. Apoptosis, sometimes called 'cell suicide', is a complex process involving a series of morphological and biochemical changes in cells, including DNA fragmentation, chromatin condensation, apoptotic body formation, membrane blebbing and cell shrinkage (22-24). The analysis of apoptosis can be used to determine the cytotoxic activity of biotoxins.

In this report, YTX-induced apoptosis as well as morphological and biochemical changes were investigated in a HeLa cell line. The study was undertaken to elucidate the apoptotic activity of $P$. reticulatum extract and to provide an analysis of $P$. reticulatum production. It is the first study in China to focus on the cytotoxic activity of YTXs in $P$. reticulatum extract (PRE). 


\section{Materials and methods}

\section{Sources of toxins}

Toxin standards. OA and YTX standards for the cytotoxic experiments were purchased from the NRC (National Research Council, Canada) and dissolved in RPMI-1640 medium to a final concentration of $2 \mathrm{ng} / \mu \mathrm{l}$.

Cell culture. A YTX-producing strain of $P$. reticulatum was purchased from the Provasoli-Guillard National Center for Culture of Marine Phytoplankton (USA). The strain was adapted in a silicate-free L1 medium prepared from filtered seawater (25). All cultures were inoculated with 500 cells/ $\mathrm{ml}$ in 2,000 $\mathrm{ml}$ borosilicate glass bottles containing $1,800 \mathrm{ml}$ of the same medium as stock. The inocula were maintained in thermostated chambers at $20^{\circ} \mathrm{C}$ in Erlenmeyer flasks. A 12:12 h light/dark cycle was used with an average irradiance on the surface of the culture. Lighting was provided by cool white fluorescent lamps $(30 \mathrm{~W})$.

Extraction of yessotoxins. The $P$. reticulatum cultures were filtered using a $0.45-\mu \mathrm{m}$ cellulose acetate membrane and immersed in the extraction solvent ( $80 \%$ methanol, v/v). The sample was then vortexed for $1 \mathrm{~min}$, homogenized in an ultrasonic bath for $10 \mathrm{~min}$, soaked for $30 \mathrm{~min}$ and washed again in an ultrasonic bath for $10 \mathrm{~min}$. The sample was then centrifuged for $10 \mathrm{~min}$ at $3,000 \mathrm{rpm}$ and filtered with single-use syringe filters $(0.45-\mu \mathrm{m}$, polypropylene). For the HeLa cell experiments, the extract was further purified using a solid phase extraction column.

Cell culture and treatment. Human cervical cancer HeLa cells were donated by the Institute of Oceanology, CAS (Chinese Academy of Sciences, Qingdao, China) and seeded in $25 \mathrm{~cm}^{2}$ flasks. HeLa cells were cultured in RPMI-1640 medium (Gibco, USA) with $300 \mathrm{mg} / \mathrm{L}$ L-glutamine, $100 \mathrm{U} / \mathrm{ml}$ penicillin and $100 \mu \mathrm{g} / \mathrm{ml}$ streptomycin. Fetal calf serum (FCS) (TBD, China) (15\%) was added to the medium. Cells were maintained at $37^{\circ} \mathrm{C}$ until $80-90 \%$ confluence was reached. For microplate assays, the split cells were trypsinized after reaching optimum confluence, and the concentration of the culture was adjusted to $1 \times 10^{4}$ cells $/ \mathrm{ml}$. Following an additional incubation of $48 \mathrm{~h}$ at $37^{\circ} \mathrm{C}$, cells grown in microplates were used for the microplate assays.

Cell proliferation assay. The inhibition of cell proliferation by PRE was detected by 3-(4,5)-dimethylthiazol-2-y1)-3,5diphenyltetrazolium bromide (MTT). Cells were placed in microplates at an initial density of $1 \times 10^{4}$ cells/well. Various concentrations of PRE were added to each well, then the cells were incubated at $37^{\circ} \mathrm{C}$ for $44 \mathrm{~h}$. The control group was treated simultaneously with solvent only. Following the initial incubation, MTT solution was added, and samples were further incubated for $4 \mathrm{~h}$ at $37^{\circ} \mathrm{C}$. The absorbance at $490 \mathrm{~nm}$ was read by an ELISA reader following the addition of dimethyl sulphoxide (DMSO, $150 \mu \mathrm{l} /$ well) as a stop solution. The inhibition ratio (\%) was calculated using the equation: inhibition ratio $(\%)=\left(1-\mathrm{A}_{\text {treatment }} / \mathrm{A}_{\text {control }}\right) \times 100 \%$.

Morphological changes. Morphological changes in the HeLa cell groups treated with $50 \mathrm{ng} / \mathrm{ml}$ of the standards and various concentrations of PRE were monitored under an inverted light microscope. After $24 \mathrm{~h}$ of treatment, cells were stained with Hoechst 33342 and PI for $20 \mathrm{~min}$, then washed with phosphate-buffered saline (PBS). Cell nuclei were then visualized using a UV fluorescence microscope (Nikon, Japan) to detect morphological evidence of apoptosis.

DNA fragmentation. The presence of a 'ladder-like' DNA fragmentation pattern typical of apoptotic cells was evaluated after $48 \mathrm{~h}$ of exposure to medium containing $50 \mathrm{ng} / \mathrm{ml}$ of the toxin standards or extract at a volume of 3,6 or $9 \%(6$, 12 or $18 \mu \mathrm{l}$ in $200 \mu \mathrm{l}$ ). There was also a blank group with no additive and a positive control using $\mathrm{H}_{2} \mathrm{O}_{2}$. To differentiate the effect of the solvent, an $80 \%$ (v/v) methanol group was added using the same concentration as the maximum dose level of the extract.

Both floating and attached cells in medium were collected, washed in PBS and resuspended in $50 \mu$ l lysis buffer, $20 \mathrm{mM}$ EDTA, $100 \mathrm{mM}$ Tris/ $\mathrm{HCl}(\mathrm{pH} 8.0)$ and $0.8 \%$ (w/v) sodium dodecyl sulfate. After treatment with RNase A $(1 \mathrm{mg} / \mathrm{ml}$, $10 \mu \mathrm{l}$ ) at $37^{\circ} \mathrm{C}$ for $1 \mathrm{~h}$, DNA samples were added to $10 \mu \mathrm{l}$ proteinase $\mathrm{K}(20 \mathrm{mg} / \mathrm{ml})$ and incubated at $55^{\circ} \mathrm{C}$ for at least $3 \mathrm{~h}$. Electrophoresis of the extracted DNA, to which a 10X loading buffer had already been added, was carried out on $2.0 \%$ agarose gels; a 200-bp DNA marker was used to compare the size of the DNA fragments. DNA bands were visualized after ethidium bromide staining (Molecular Probes Inc.).

Mitochondrial membrane potential. Mitochondrial transmembrane potential (MTP) was measured using flow cytometry with the fluorescent probe rhodamine 123 ( $\mathrm{Rh} 123$ ). Rh 123 accumulates in normal mitochondrial due to its high negative charge; loss of MTP leads to the release of Rh 123 and a reduction in its fluorescence intensity. Before treatment, $\mathrm{Rh}$ 123 was diluted in PBS to a final concentration of $10 \mathrm{mg} / \mathrm{l}$. Treated cells were incubated for 8, 16, 24, 32, 40 or $48 \mathrm{~h}$. After treatment, $\sim 10^{6}$ cells were collected by trypsinization, washed twice in PBS and incubated with $\mathrm{Rh} 123$ for $30 \mathrm{~min}$ at $37^{\circ} \mathrm{C}$ in the dark. The samples were analyzed by flow cytometry.

Analysis of the extract by liquid chromatography-tandem mass spectrometry (LC-MS/MS). LC-MS/MS analysis was performed using an Agilent 1200 high-performance liquid chromatography (HPLC) system with a G1311A binary pumping system and a G1329A automated injector coupled to an API4000 mass spectrometer with Turbo Spray interface. The column $(100 \times 4.6 \mathrm{~mm})$ was packed with 3.5- $\mu \mathrm{m}$ Agilent Zorbax SB-C18 and maintained at $20^{\circ} \mathrm{C}$. The extract was analyzed in the negative mode.

The YTX standard was used as the calibration standard (200 $\mathrm{ng} / \mathrm{ml}$ ), and was prepared by appropriate dilution with methanol and stored at $-80^{\circ} \mathrm{C}$.

The mobile phase consisted of acetonitrile and water arranged in different proportions as solvent $\mathrm{A}(10: 90, \mathrm{v} / \mathrm{v})$ and solvent B (90:10, v/v), both containing $53 \mathrm{mM}$ formic acid and $5 \mathrm{mM}$ ammonium formate. Gradient elution was carried out according to the following program: $\min 0-5,100 \% \mathrm{~A}$; min $5-10,40 \%$ A/60\% B; $\min 10-20,100 \% \mathrm{~B}$; $\min 20-45,100 \% \mathrm{~A}$. The flow rate was $0.3 \mathrm{ml} / \mathrm{min}$, and $20 \mu \mathrm{l}$ of the sample was injected into the column at room temperature. The exact mass spectrometer conditions of the YTXs are listed in Table I. 
Table I. Mass spectrometer conditions of the yessotoxins.

\begin{tabular}{llrrr}
\hline Toxin & Mode & MRM transition $(m / z>m / z)$ & DP & FP \\
\hline YTX & Negative & $1141.5>1061.5$ & -12 & -180 \\
Homo-YTX & Negative & $1155.5>1075.5$ & -12 & -180 \\
$45-O H-Y T X$ & Negative & $1157.5>1077.5$ & -12 & -45 \\
$45-O H-h o m o-Y T X$ & Negative & $1171.5>1091.5$ & -12 & -180 \\
\hline
\end{tabular}

CE, collision energy; DP, declustering potential; FP, focusing potential; MRM, multiple reaction monitoring; YTX, yessotoxin.

\section{Results}

Antiproliferative activity of the extract. To investigate the inhibitory effect of PRE on HeLa cells, an MTT assay was conducted. HeLa cells were treated with PRE dissolved in $80 \%$ methanol and the same volume of solvent as a control. As shown in Fig. 1, PRE inhibited the growth of HeLa cells in a concentration-dependent manner compared to the controls. In order to reduce the effect of $80 \%$ methanol, the extract used in the subsequent experiment did not exceed $10 \%$.

Morphological changes. Morphological changes were observed under a microscope. The cells of the untreated control group and the group treated with $80 \%$ methanol underwent rapid growth, and their nuclei were round and clear. Cells in the positive control group treated with $0.3 \%$ $\mathrm{H}_{2} \mathrm{O}_{2}$ were irregularly shaped; some cells were broken with no content, while the nuclei were marginalized in other cells. Morphological changes characteristic of apoptosis were noted in cells treated with $50 \mathrm{ng} / \mathrm{ml}$ of the toxin standards and with the different PRE concentrations for $48 \mathrm{~h}$ (Fig. 2).

Hoechst 33342-positive cells were defined as being in early-stage apoptosis, while PI-positive cells were determined to be in late-stage apoptosis or even necrosis. Upon fluorescent microscopy, the HeLa cells treated with the standards and the indicated concentrations of the extract for $24 \mathrm{~h}$ presented the typical features of early-stage apoptosis. Bright nuclear condensation was noted by Hoechst 33342 staining, and apoptotic bodies were observed as masses in the cells (Fig. 3). The apoptotic and total cells in each field of view were counted, and the ratio of apoptotic cells was calculated (Fig. 4). The numbers of broken and necrotic cells increased in conjunction with increasing concentrations of PRE.

DNA fragmentation. Nuclear DNA fragmentation was examined using agarose gel electrophoresis. As shown in Fig. 5, DNA laddering was noted $48 \mathrm{~h}$ after the HeLa cells were exposed to various concentrations of PRE and the toxin standards.

Assessment of changes in mitochondrial membrane potential. As shown in Fig. 6, the MTP of the treated cells decreased with increasing time. When the cells were incubated with the YTX and OA standards or with $3 \%$ PRE for $8 \mathrm{~h}$, the MTP began to decrease; $32 \mathrm{~h}$ after incubation, the decrease in MTP had not progessed further, indicating that the standards and PRE affected MTP within the first $32 \mathrm{~h}$.

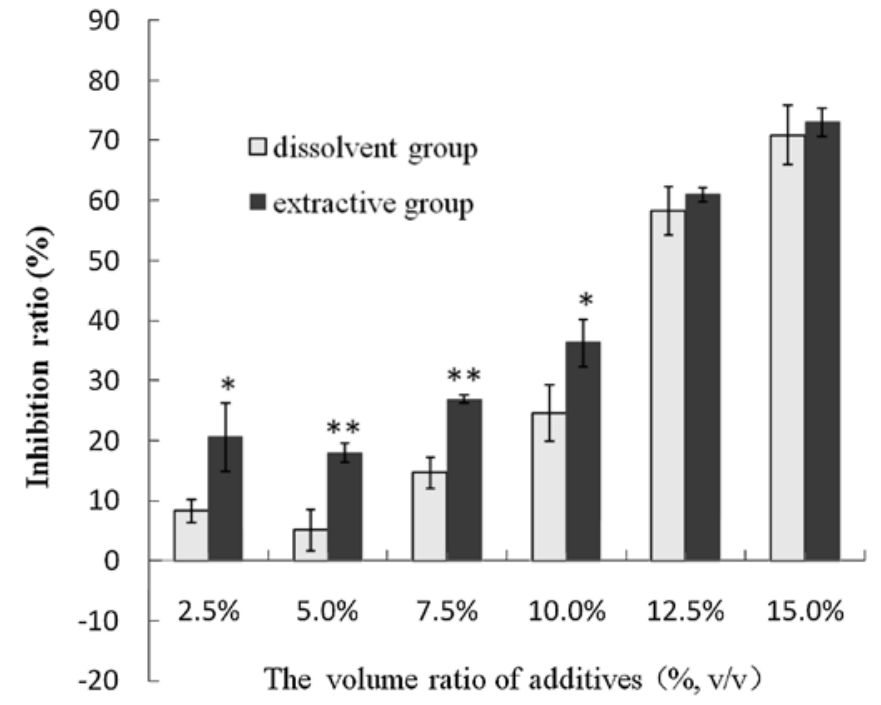

Figure 1. Inhibitory effect of the extract on the viability of HeLa cells in comparison with the dissolvent group. ${ }^{*} \mathrm{P}<0.01$.

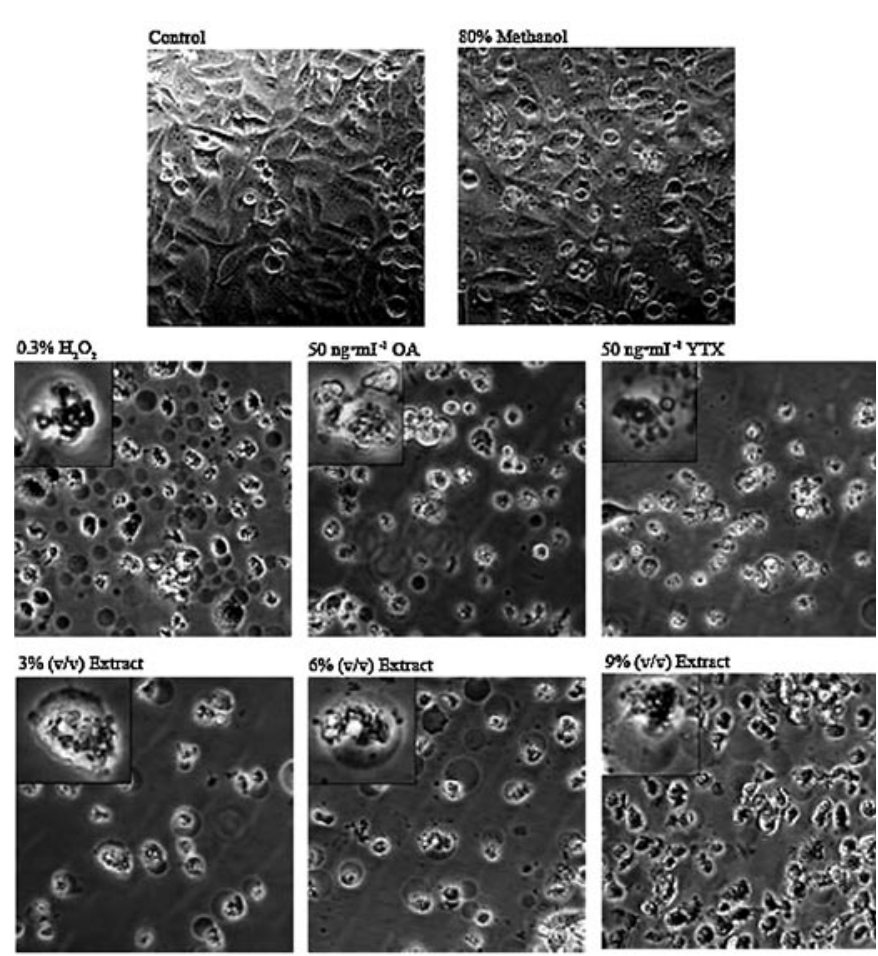

Figure 2. Morphological changes in HeLa cells treated with the standards and different concentrations of extract for $48 \mathrm{~h}$ observed with an inverted microscope (x200) 


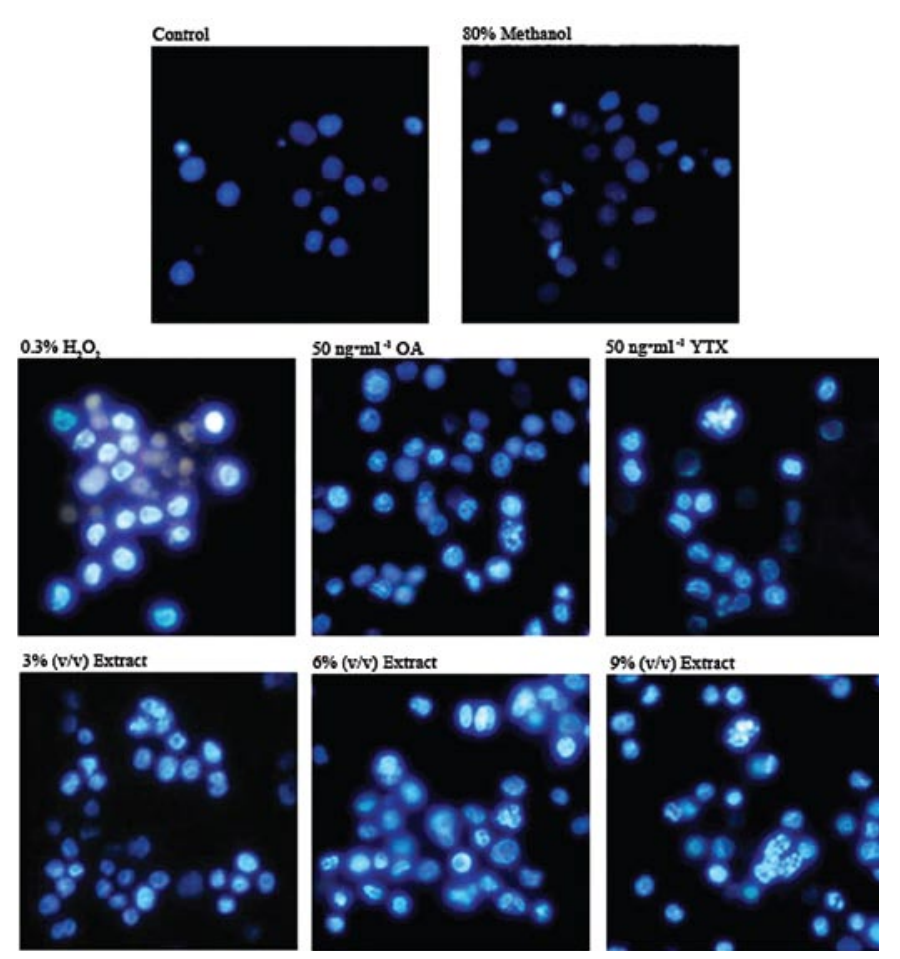

Figure 3. Fluorescent staining (Hoechst 33342 and PI) of nuclei in toxintreated or untreated cells (x200).

Analysis of extract by LC-MS/MS. The extract was quantified by comparison with an authentic standard of YTX. The assumption was made that closely related analogues of homo-YTX and derivatives such as 45-OH-YTX, 45-OHhomo-YTX would give the same responses as the parent toxins. Calibration curves from the same quantitative standard were therefore applied to estimate the concentration of the respective related compounds.

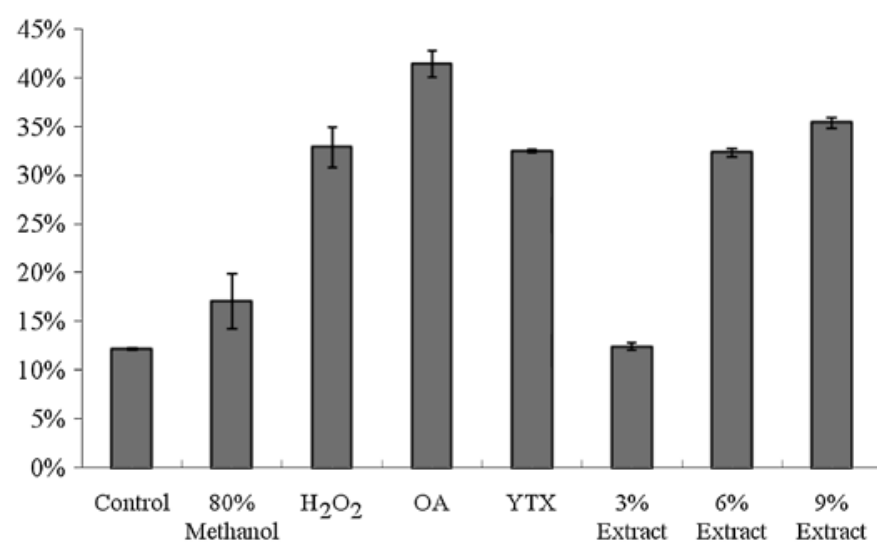

Figure 4. Ratio of apoptotic cells in the treatment groups.

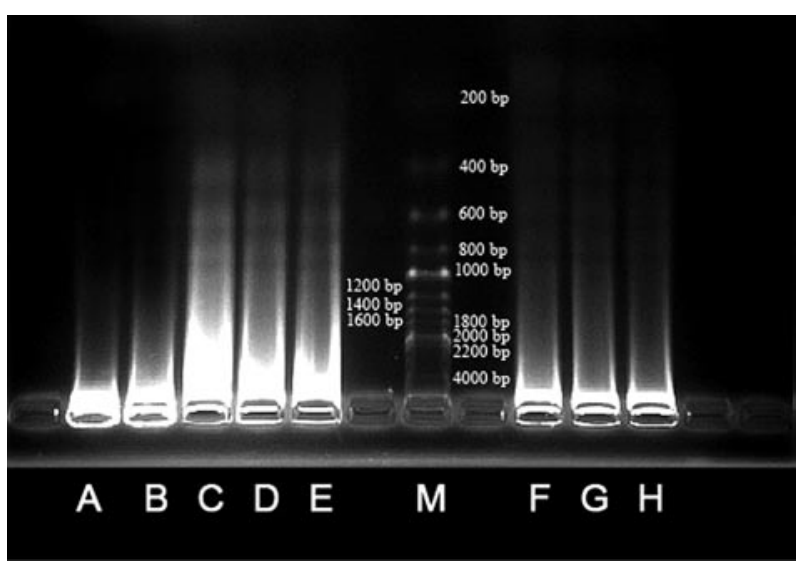

Figure 5. DNA fragmentation measured by ethidium bromide staining. (A) Control, (B) $80 \%$ methanol, (C) $0.3 \% \mathrm{H}_{2} \mathrm{O}_{2}$, (D) $50 \mathrm{ng} / \mathrm{ml} \mathrm{OA}$, (E) $50 \mathrm{ng} / \mathrm{ml}$ YTX, (M) 200-bp DNA ladder marker, (F) 3\% (v/v) extract, (G) 6\% (v/v) extract, (H) $9 \%$ (v/v) extract.
A
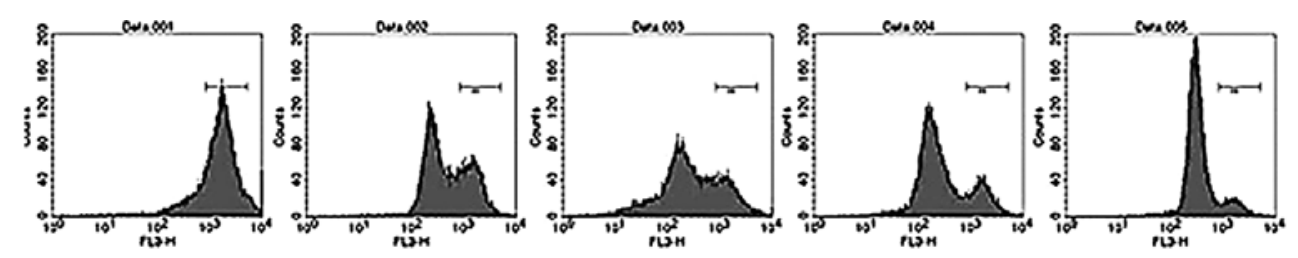

B
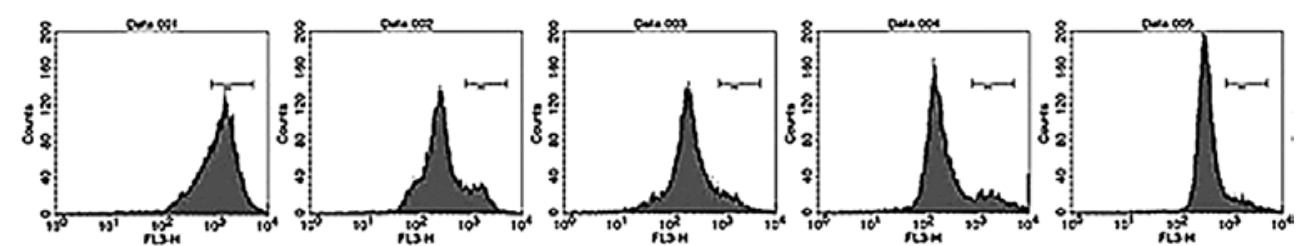

C
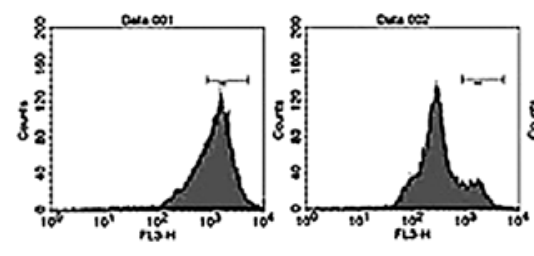

$8 \mathrm{~b}$
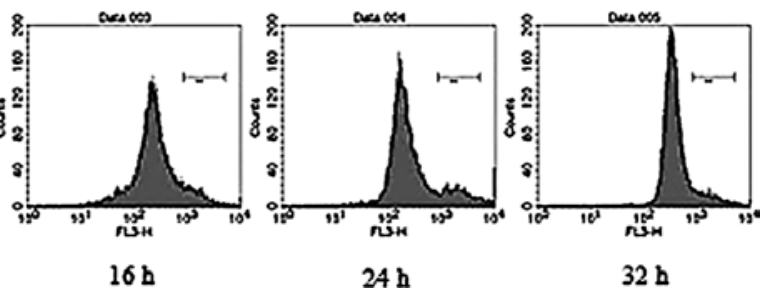

Figure 6. Changes in the mitochondrial membrane potential of Hela cells treated with OA standard (A), YTX standard (B) or 3\% extract (C) for different time periods. 
Cultured $P$. reticulatum cells were extracted by sonicating with methanol. The crude extract was directly analyzed by LC-MS/MS. Although homo-YTX, 45-OH-YTX and 45-OH-homo-YTX were detected in the resulting PRE, the amount of YTZ was too small to detect. In the study, $4.5 \times 10^{7}$ $P$. reticulatum cells were collected, compared with the YTX standard $(200 \mathrm{ng} / \mathrm{ml})$, and analyzed; the products of $P$. reticulatum included $2.88 \mathrm{pg} /$ cell for homo-YTX, $0.842 \mathrm{pg} / \mathrm{cell}$ for 45-OH-YTX and $0.0681 \mathrm{pg} / \mathrm{cell}$ for 45-OH-homo-YTX.

\section{Discussion}

In this study, we showed that apoptotic events were induced by PRE in a cell-specific manner in HeLa human cervical cancer cells, and compared these effects with those of OA and YTX standards. After treatment with various PRE concentrations, the morphology of the cells showed typical characteristics of apoptosis, including cell shrinkage, nuclear fragmentation and chromatin condensation.

To determine the extent of apoptosis in HeLa cells, Hoechst 33342 and PI staining were used to observe morphological changes in HeLa cells treated or not with the toxins. Hoechst stains are fluorescent stains used for labeling DNA in fluorescence microscopy and for fluorescent-activated cell sorting (FACS), and can be used on live or fixed cells (26). Since Hoechst 33342 binds to DNA, it disrupts DNA replication during cell division. PI is an intercalating agent and fluorescent molecule that is used to stain DNA. It can be used to differentiate necrotic, apoptotic and normal cells. PI readily enters and stains non-viable cells, but cannot cross the membrane of viable cells. In the present study, in HeLa cells treated with the toxin standards or various concentrations of the extract for $48 \mathrm{~h}$ then stained with Hoechst 33342 and PI, morphological alterations characteristic of early-stage apoptosis were observed, including chromatin condensation and nuclear fragmentation. However, few cells were stained by PI, indicating that most of the treated cells were in the early stages of apoptosis.

Changes in mitochondrial membrane permeability transition are a common and crucial mechanism in cell death (27). It has been found that MTP is an early event in apoptosis (28-30). In most models of apoptosis, the disruption of MTP often precedes nuclear DNA degradation (31-34). In our study, the toxin standards and the extract decreased MTP, indicating the initiation of apoptosis in treated cells. It has been reported that YTXs induce the accumulation of $\mathrm{Ca}^{2+}$. We previously investigated YTX toxicity in Purkinje cells from the cerebellum of ICR mice, and showed a more positive response to YTX by immunohistochemical staining of the calcium-binding protein S-100. Further investigation of the mechanisms behind the effect of YTX are planned by our group.

In the marine biotoxin field, LC-MS is becoming the prime technology for improved screening due to its high sensitivity and specificity (35-37). Tandem mass spectrometry (LC-MS/MS) has been developed to detect marine biotoxins in plankton and shellfish. In the present study, the retention time and mass spectra of each peak were compared with those of individual reference samples injected under the same experimental conditions. The YTX content of PRE was also determined by comparison with an individual standard solu- tion of YTX injected under the same experimental conditions. As analyzed by LC-MS/MS, YTX levels in the PRE were too low to be detected. Although there were no appropriate standards for YTX analogues, the assumption was made that the closely related analogue, homo-YTX, and derivatives such as 45-OH-YTX and 45-OH-homo-YTX gave the same molar response as YTX. As a result, the YTX analogue content in the extract of $P$. reticulatum was calculated as $2.88 \mathrm{pg} / \mathrm{cell}$ for homo-YTX, $0.842 \mathrm{pg} / \mathrm{cell}$ for 45-OH-YTX and $0.0681 \mathrm{pg} /$ cell for 45-OH-homo-YTX. Different strains of $P$. reticulatum have different characteristics and products. The strain used in the present study produced low levels of YTX but high levels of homo-YTX and 45-OH-YTX. Apoptosis was observed in HeLa cells after incubation with PRE. However, subsequent studies planned by our group of $P$. reticulatum in China are required to cofirm the toxicity of these compounds.

\section{Acknowledgements}

This study was supported by the International Cooperation Program of the Ministry of Science and Technology of the People's Republic of China (no. 2007DFA30710).

\section{References}

1. Murata M, Masanori K, Lee JS and Yasumoto T: Isolation and structure of yessotoxin, a novel polyether compound implicated in diarrhetic shellfish poisoning. Tetrahedron Lett 28: 5869-5872, 1987.

2. Satake M, MacKenzie L and Yasumoto T: Identification of Protoceratium reticulatum as the biogenetic origin of yessotoxin. Nat Toxins 5: 164-167, 1997.

3. Tubaro A, Sidari L, della Loggia R and Yasumoto T: Occurrence of homoyessotoxin in phytoplankton and mussels from Northern Adriatic Sea. In: Harmful Algae, Xunta de Galicia and Intergovernmental Oceanographic Commission of UNESCO. Reguera B, Blanco J, Fernández ML and Wyatt T (eds). Grafisant, Santiago de Compostela, pp470-472, 1998.

4. Lee JS, Tangen K, Dahl E, Hovgaard $\mathrm{P}$ and Yasumoto T: Diarrhetic shellfish toxins in Norwegian mussels. Nippon Suisan Gakkaishi 54: 1953-1957, 1988.

5. Yasumoto $\mathrm{T}$ and Takizawa A: Fluorometric measurement of yessotoxins in shellfish by high-pressure liquid chromatography. Biosci Biotechnol Biochem 61: 1775-1777, 1997.

6. Draisci R, Ferretti E, Palleschi L, Marchiafava C, Poletti R, Milandri A, Ceredi A and Pompei M: High levels of yessotoxin in mussels and presence of yessotoxin and homoyessotoxin in dinoflagellates of the Adriatic Sea. Toxicon 37: 1187-1193, 1999.

7. Stobo LA, Lewis J, Quilliam MA, Hardstaff WR, Gallacher S, Webster L, Smith E and McKenzie M: Detection of yessotoxin in UK and Canadian isolates of phytoplankton and optimization and validation of LC-MS methods. In: Gulf Fisheries Centre. Bates S (ed). Moncton, New Brunswick, pp8-14, 2003.

8. Paz B, Riobó P, Fernández ML, Fraga $\mathrm{S}$ and Franco JM: Production and release of yessotoxins by the dinoflagellates Protoceratium reticulatum and Lingulodinium polyedrum in culture. Toxicon 44: 251-258, 2004.

9. Paz B, Riobó P, Ramilo I and Franco JM: Yessotoxins profile in strains of Protoceratium reticulatum from Spain and USA. Toxicon 50: 1-17, 2007.

10. Ogino H, Kumagai $M$ and Yasumoto T: Toxicologic evaluation of yessotoxin. Nat Toxins 5: 255-259, 1997.

11. Yasumoto $\mathrm{T}$ and Murata M: Marine toxins. Chem Rev 93: 1897-1909, 1993.

12. EC: Commission Decision 2002/225/EC of 15 March 2002 laying down detailed rules for the implementation of Council Directive 91/492/EEC as regards the maximum levels and the methods of analysis of certain marine biotoxins in bivalve molluscs, echinoderms, tunicates and marine gastropods. Official Journal of the European Communities, pp62, 2002. 
13. Boni L: Red tides of the coast of Emilia Romagna (north western Adriatic Sea) from 1975 to 1982 . Inf Bot It 15: 18-24, 1983.

14. Ciminiello P, Dell'Aversano C, Fattorusso E, Forino M, Magno S, Guerrini F, Pistocchi R and Boni L: Complex yessotoxins profile in Protoceratium reticulatum from northwestern Adriatic sea revealed by LC-MS analysis. Toxicon 42: 7-14, 2003.

15. Morton SL, Vershinin A, Leighfield TA, Smith L and Quilliam M: Identification of yessotoxin in mussels from the Caucasian Black Sea Coast of the Russian Federation. Toxicon 50: 581-584, 2007.

16. Arévalo F, Pazos Y, Correa J, Salgado C, Moroño A, Paz B and Franco JM: First report of yessotoxins in mussels of Galician Rías during a bloom of Lingulodinium polyedra Stein (Dodge). In: Henshilwood K, Deegan B, McMahon T, Cusack C, Keaveney S, Silke J, O'Cinneide M, Lyons D and Hess P (eds). Galway, Ireland, pp184-189, 2006.

17. Terao K, Ito E, Yanagi $\mathrm{T}$ and Yasumoto T: Histopathological studies on experimental marine toxin poisoning. 5. The effects in mice of yessotoxin isolated from Patinopecten yessoensis and of a desulfated derivative. Toxicon 28: 1095-1104, 1990.

18. Aune T, Sorby R, Yasumoto T, Ramstad H and Landsverk T: Comparison of oral and intraperitoneal toxicity of yessotoxin towards mice. Toxicon 40: 77-82, 2002.

19. Espenes A, Aasen J, Hetland D, Satake M, Smith A, Eraker N and Aune T: Toxicity of yessotoxin in mice after repeated oral exposure. 5th International Conference on Molluscan Shellfish Safety, 14th-18th June, Galway, Ireland, 2004.

20. Malaguti C, Ciminiello P, Fattorusso E and Rossini G: Caspase activation and death induced by yessotoxin in HeLa cells. Toxicol in Vitro 16: 357-363, 2002.

21. Leira F, Alvarez C, Vieites JM, Vieytes MR and Botana LM: Characterization of distinct apoptotic changes induced by okadaic acid and yessotoxin in the BE (2)-M17 neuroblastoma cell line. Toxicol in Vitro 16: 23-31, 2002.

22. Kerr J, Wyllie A and Currie AR: Apoptosis: a basic biological phenomenon with wide-ranging implications in tissue kinetics. Br J Cancer 26: 239-257, 1972.

23. Martin S and Green D: Protease activation during apoptosis: death by a thousand cuts? Cell 82: 349-352, 1995.

24. Earnshaw W, Martins L and Kaufmann S: Mammalian caspases: structure, activation, substrates and functions during apoptosis Annu Rev Biochem 68: 383-424, 1999.

25. Guillard RRL and Hargraves PE: Stichochrysis immobilis is a diatom, not a chrysophyte. Phycologia 32: 234-236, 1993.

26. Telford WG, Komoriya A and Packard BZ: Multiparametrci analysis of apoptosis by flow and image cytometry. In: Flow Cytometry Protocols (Methods in Molecular Biology). Hawley TS and Hawley RG (eds). Humana Press, Totowa, pp141-160, 2004
27. Lemasters JJ, Nieminen AL, Qian T, Trost LC, Elmore SP, Nishimura Y, Crowe RA, Cascio WE, Bradham CA, Brenner DA and Herman B: The mitochondrial permeability transition in cell death: a common mechanism in necrosis, apoptosis and autophagy. Biochim Biophys Acta 1366: 177-196, 1998.

28. Kroemer G, Petit PX, Zamzami N, Vayssiere JL and Mignotte B: The biochemistry of programmed cell death (Review). FASEB J 9: 1277-1287, 1995.

29. Green DR and Reed JC: Mitochondria and apoptosis. Science 281: 1309-1312, 1998

30. Kroemer G and Reed JC: Mitochondrial control of cell death. Nat Med 6: 513, 2000

31. Cossarizza A, Franceschi C, Monti D, Salvioli S, Bellesia E, Rivabene R, Biondo L, Rainaldi G, Tinari A and Malorni W: Protective effect of $\mathrm{N}$-acetylcysteine in tumor necrosis factoralphainduced apoptosis in U937 cells: the role of mitochondria. Exp Cell Res 220: 232-240, 1995.

32. Petit PX, Lecoeur H, Zorn E, Dauguet C, Mignotte B and Gougeon ML: Alterations of mitochondrial structure and function are early events of dexamethasone-induced thymocyte apoptosis. J Cell Biol 130: 157-167, 1995.

33. Zamzami N, Marchetti P, Castedo M, Decaudin D, Macho A Hirsch T, Susin SA, Petit PX, Mignotte B and Kroemer G: Sequential reduction of mitochondrial transmembrane potential and generation of reactive oxygen species in early programmed cell death. J Exp Med 182: 367-377, 1995.

34. Marchetti P, Susin SA, Decaudin D, Gamen S, Castedo M, Hirsch T, Zamzami N, Naval J, Senik A and Kroemer G: Apoptosis associated derangement of mitochondrial function in cells lacking mitochondrial DNA. Cancer Res 56: 2033-2038, 1996.

35. Quilliam MA: Liquid chromatography-mass spectrometry: a universal method for analysis of toxins? In: Harmful Algae. Xunta de Galacia, Intergovernmental Oceanographic Commission of UNESCO. Reguera B, Blanco J, Fernandez ML and Wyatt T (eds). Vigo, Spain, pp509-514, 1998.

36. Quilliam MA, Hess P and Dell'Aversano C: Recent developments in the analysis of phycotoxins by liquid chromatography-mass spectrometry. In: Mycotoxins and Phycotoxins in Perspective at the Turn of the Millenium. DeKoe WJ, Samson RA, van Egmond HP, Gilbert J and Sabino M (eds). Wageningen, The Netherlands, pp383-391, 2001.

37. Goto H, Igarashi T, Yamamoto M, Yasuda M, Sekiguchi R, Watai M, Tanno K and Yasumoto T: Quantitative determination of marine toxins associated with diarrhetic shellfish poisoning by liquid chromatography coupled with mass spectrometry. J Chromatogr A 907: 181-189, 2001. 